\title{
Response of Black Madras Purple Rice to Pruning and Application of Unitas Super Liquid Organic Fertilizer
}

DOI: $10.18196 /$ pt.2019.090.26-32

\author{
Jamilah*, Widodo Haryoko, Weki Akriweldi \\ Department of Agrotechnology, Faculty of Agriculture, Universitas Tamansiswa Padang, \\ Jl. Tamansiswa No. 9 Padang, 25138, Indonesia \\ *Corresponding author, email: jamilahfatika@gmail.com
}

\begin{abstract}
Indonesian rice yields are still relatively low. One of the efforts to increase the yield of rice plants is to trim the foliages before flowering, in addition to the application of 'Unitas Super' liquid organic fertilizer (LOF). The study was carried out in the Lubuk Lintah Village, Padang City in May - September 2017. The aim of the study was to investigate the effectiveness of pruning, as a source of forage, and the concentration of 'Unitas Super' liquid organic fertilizer in improving rice yields. The experiment was arranged in split plot design with main plots consisting of 2 levels, namely pruning at 45 days and without pruning. The subplots consisted of 3 concentrations of 'Unitas Super' liquid organic fertilizer, namely $0 \mathrm{ml} \mathrm{L}^{-1}, 50 \mathrm{ml} / \mathrm{L}^{-1}$, and $100 \mathrm{ml} \mathrm{L}^{-1}$. All treatments were replicated 3 times. Data were analyzed statistically using the F test at 5\% and tested using LSD at 5\%. According to the results of the observations, it can be concluded that pruning reduced the weight of 1000 seeds and panicle length, but did not reduce the yield of harvested dry grain and harvest index. Application of 'Unitas Super' liquid organic fertilizer did not significantly increase the growth and yield of Black Madras purple rice. The highest dry grain yield was 4.04 tha- observed in plants sprayed with $50 \mathrm{ml} \mathrm{L-1} \mathrm{'Unitas} \mathrm{Super'} \mathrm{liquid} \mathrm{organic} \mathrm{fertilizer} \mathrm{without} \mathrm{pruning} \mathrm{treatment.}$

Keywords: Black madras purple rice, Pruning, Unitas Super liquid organic fertilizer
\end{abstract}

\section{ABSTRAK}

Produksi beras Indonesia masih relatif rendah. Salah satu upaya untuk meningkatkan hasil tanaman padi adalah dengan memangkas dedaunan sebelum berbunga, di samping penerapan pupuk organik cair (LOF) 'Unitas Super'. Penelitian dilakukan di Desa Lubuk Lintah, Kota Padang pada bulan Mei - September 2017. Tujuan dari penelitian ini adalah untuk menvelidiki efektivitas pemangkasan, sebagai sumber pakan, dan konsentrasi pupuk organik cair 'Unitas Super' dalam meningkatkan hasil padi. Percobaan disusun dalam desain petak terbagi dengan plot utama yang terdiri dari 2 level, yaitu pemangkasan pada 45 hari dan tanpa pemangkasan. Sub-plot terdiri dari 3 konsentrasi pupuk organik cair 'Unitas Super', yaitu $0 \mathrm{ml} \mathrm{L-1,50} \mathrm{ml} \mathrm{L-1,} \mathrm{dan} 100 \mathrm{ml} \mathrm{L}^{-1}$. Semua perawatan diulang 3 kali. Data dianalisis secara statistik menggunakan uji F pada 5\% dan diuji menggunakan LSD pada 5\%. Menurut hasil pengamatan, dapat disimpulkan bahwa pemangkasan mengurangi berat 1000 biji dan panjang malai, tetapi tidak mengurangi hasil panen gabah kering dan indeks panen. Penerapan pupuk organik cair 'Unitas Super' tidak secara signifikan meningkatkan pertumbuhan dan hasil beras ungu Madras Hitam. Hasil gabah kering tertinggi adalah 4,04 t ha-1 yang diamati pada tanaman yang disemprot dengan $50 \mathrm{ml} \mathrm{L}^{-1}$ 'pupuk organik cair Unitas Super 'tanpa perawatan pemangkasan.

Kata Kunci: Beras ungu black madras, Pemangkasan, Pupuk organic cair unitas super

\section{INTRODUCTION}

Rice is the main crop in Indonesia due to its is an idea considered dangerous for the survival of status as staple food. Therefore, the development engineering of various rice varieties is also very rapid in Indonesia. Rice can grow well in Indonesia with an average yield of 5-6 tons / ha (BPS, 2016). These results have not shown a significant increase over the past 10 years. Although the technology of rice cultivation has been developed, various constraints limit the significant increase in rice yields. Thus, providing appropriate technology in the farming community is necessary in efforts to optimize the rice yield. the plants. Farmers still feel the fear of crop failure if plants are pruned before flowering. This excessive fear is very natural if they have never seen or tried it as an innovation in the field. Based on the report of Jamilah, Fadhila, \& Mulyani (2017), there was a decrease of rice grain yield and harvest age of cv. Pandan Wangi and harvest age in cv. Cisokan (Jamilah \& Helmawati, 2015). Therefore, trials are needed for various rice varieties to get rice species that are immune to pruning. According to Jamilah (2017), pruning of rice plants during the maximum Foliage pruning of rice plants before flowering vegetative period will cause the plants to be resis- 
tant to risk of collapse due to strong winds with rain when the plants enter the fruit ripening phase.

The liquid organic fertilizer (LOF) derived from shrubs from Chromolaena odorata which is enriched with various other agricultural wastes such as urine, banana stems, coconut husks, and cow dung, named 'Unitas Super' has been tested for its superiority by comparing various commercial liquid fertilizers. This has been reported by Fadhila (2016); Rocki (2016); Lisa Rahmadani (2016); that 'Unitas Super' LOF has several advantages in increasing rice growth compared to 'K-Get' and 'TNT' liquid fertilizer. In general, they applied as much as 200 $\mathrm{ml} \mathrm{L}^{-1}$ of LOF sprayed on the canopy part of the rice plant evenly every 2 weeks. Furthermore, the trial conducted by Riswandi (2017) and Antoni (2017) proved that 'Unitas Super' LOF as much as $100 \mathrm{ml} \mathrm{L}^{-1}$ applied every 2 weeks is still superior compared to 'NASA' Liquid Fertilizer. Therefore, the concentration of 'Unitas Super' LOF can be decreased to get more efficient and effective treatment so as to benefit farmers.

In general, they applied the LOF by reducing $25 \%$ of the dose of synthetic fertilizer. In addition, Erianto (2016) obtained the superiority of 'Unitas Super' LOF compared to NASA on onion plants. There is still no information on the appropriate concentration to increase the growth and yield of rice plants. Each rice variety also gave a different response to the applied LOF.

The cultivation of purple rice (Black Madras) is still not popular in West Sumatra. High anthocyanin content in the leaves is thought to cause the plant to have purple leaves. It is expected that foliage pruning in purple leaved rice will produce a higher nutrient content than green leaved rice plants such as cv. Pandan Wangi and cv. Cisokan. Therefore, the selection of Black Madras rice is important in this experiment. In addition, it is also important to know the response of Black
Madras rice to various concentrations of 'Unitas Super' LOF given. The aim of the experiment was to test the effectiveness of foliage pruning of Black Madras rice, as a provider of animal feed, and the concentration of 'Unitas Super' LOF in increasing the rice yields.

\section{MATERIALS AND METHODS}

\section{Experimental Design}

The study was conducted using purple rice cv. Black Madras in March 2017 - July 2017. Experiments were arranged in split plot design with main plot consisting of pruning treatment, i.e. P1 (with pruning) and PO (without pruning). The application of 'Unitas Super' LOF was arranged in subplots, consisting of various concentrations, i.e. $\mathrm{FO}=0 \mathrm{ml} \mathrm{L}^{-1} ; \mathrm{F} 1=50 \mathrm{ml} \mathrm{L}^{-1}$ and $\mathrm{F} 2=100 \mathrm{ml} \mathrm{L}^{-1}$.

\section{Treatment application}

Black Madras rice seeds were sown for 3 weeks and then transferred to the field by 2 seedlings at each planting hole with planting space of $25 \mathrm{~cm}$ x $25 \mathrm{~cm}$ in a $2 \mathrm{~m} \times 2 \mathrm{~m}$ plot. Basic fertilizers given were Urea, SP36, and $\mathrm{KCl}$, as much as $75 \%$ of the recommended dose at 10 days after transplanting. Urea was given gradually, i.e. $50 \%$ at the beginning and the rest at 40 days after pruning. The plots were flooded $2 \mathrm{~cm}$ above the ground at the initial phase and to be increased according to the age of plant growth. The water height was increased when the plant was entering the flowering stage and the height was maintained until the grain filling phase. After the grain became solid, the water was slowly reduced until dry. Pruning was carried out at 40 DAP by pruning all canopy sections as high as 20 $\mathrm{cm}$ above the ground.

\section{Data Collection}

Observed variables of agronomic traits included plant height, maximum and productive tillers, 
flowering and harvesting age, panicle length, number of grains per panicle, weight of 1000 seeds, percentage of empty grain, yield per plot and per hectare and harvest index. Chemical analysis of plants was carried out in 40 days after planting (DAP) by cutting all $20 \mathrm{~cm}$ of the canopy from the ground. The variables observed included total $\mathrm{N}$, Potassium, Calcium, organic C, and C / N.

After being pruned, the fresh materials were weighed to determine the forage weight. The fresh samples of plants, then were put in an electric oven at a temperature of $80^{\circ} \mathrm{C}$ for 48 hours to obtain dry weight. The dried plant samples were then ground until smooth passing through a $2 \mathrm{~mm}$ sieve, then used for chemical analysis materials. The samples were then analyzed chemically using the Kjeldahl method for total $\mathrm{N}$ determination, an AAS tool for the determination of $\mathrm{K}$ and $\mathrm{Ca}$, and electronic device for measuring $\mathrm{P}$ and organic $\mathrm{C}$ level of plants. Determination of plant ash content was done by putting the plant samples in the furnace in 2 stages at temperatures of $300^{\circ} \mathrm{C}$ and $800^{\circ} \mathrm{C}$, up to 4 hours. The plant samples became white ash and were weighed.

\section{Data analysis}

Each treatment was replicated 3 times, resulting in 18 experimental plots. The collected data were analyzed statistically using the $\mathrm{F}$ test at 5\%, followed by Least Significant Difference (LSD) test at 5\%.

\section{RESULTS AND DISCUSSION}

Observation results on the plant height, forage weight, straw weight, maximum and productive tillers, flowering and harvesting age is presented in Table 1, Figures 1 and 2. In general, the height of pruned rice plants will decrease, as well as the weight of straw when harvested. However, the maximum number of tillers, number of productive tillers, and flowering and harvesting age of the plants were not affected by pruning at the beginning of the primordia.

Pruning did not have effects on the growth parameters except for the plant height. Pruned

Table 1. Effects of pruning and concentration of 'Unitas Super' LOF on the plant height, forage weight, straw weight, maximum number of tillers, number of productive tillers, and flowering and harvesting age of Blck Madras purple rice

\begin{tabular}{|c|c|c|c|c|c|c|c|}
\hline $\begin{array}{l}\text { Concentration of 'Unitas } \\
\text { Super' LOF }\left(\mathrm{ml} \mathrm{L}^{-1}\right)\end{array}$ & Plant height & Forage weight & Straw weight & $\begin{array}{c}\text { Maximum } \\
\text { tillers }\end{array}$ & $\begin{array}{l}\text { Productive } \\
\text { tillers }\end{array}$ & $\begin{array}{l}\text { Flowering } \\
\text { age }\end{array}$ & $\begin{array}{c}\text { Harvesting } \\
\text { age }\end{array}$ \\
\hline & $(\mathrm{cm})$ & --------(Mg r & |a-1)--------- & --------tiller & mp-------- & --------da & S---------- \\
\hline \multicolumn{8}{|l|}{ without pruning } \\
\hline 0 & 72.50 & - & 9.54 & 23.33 & 20.33 & 56.33 & 85.33 \\
\hline 50 & 76.83 & - & 9.87 & 22.83 & 22.33 & 55.33 & 86.00 \\
\hline 100 & 77.00 & - & 10.55 & 24.00 & 22.17 & 55.33 & 86.33 \\
\hline Mean & $75.44 \mathrm{a}$ & - & $9.98 \mathrm{a}$ & $23.39 \mathrm{a}$ & $21.61 \mathrm{a}$ & $55.67 \mathrm{a}$ & 85.89 a \\
\hline \multicolumn{8}{|l|}{ with pruning } \\
\hline 0 & 68.00 & 4.72 & 6.44 & 20.17 & 19.67 & 54.33 & 87.33 \\
\hline 50 & 68.83 & 5.51 & 6.13 & 21.00 & 19.50 & 55.00 & 86.33 \\
\hline 100 & 65.33 & 5.79 & 6.54 & 21.33 & 19.83 & 55.33 & 86.33 \\
\hline Mean & $65.33 \mathrm{~b}$ & 5.34 & $6.54 \mathrm{~b}$ & $21.33 \mathrm{a}$ & $19.83 \mathrm{a}$ & $55.33 \mathrm{a}$ & $86.33 \mathrm{a}$ \\
\hline CV pruning (\%) & 4.06 & & 14.66 & 16.26 & 9.91 & 2.26 & \\
\hline CV LOF (\%) & 4.48 & & 6.95 & 8.33 & 14.03 & 1.45 & \\
\hline LSD 5\% & 5.87 & & & & & & \\
\hline
\end{tabular}

Remarks: $\mathrm{P} 0=$ without pruning; $\mathrm{P} 1=$ with pruning; $\mathrm{F} 1=0 \mathrm{ml} \mathrm{L}-1 \mathrm{POC} ; \mathrm{F} 2=50 \mathrm{ml} \mathrm{L}-1 ; \mathrm{F} 3=100 \mathrm{ml} \mathrm{L}-1$. Means followed by the same lower case letters in the same column are not significantly different according to LSD at $5 \%$. 
Table 2. Effects of the concentration of 'Unitas Super' LOF on the nutrient content of Black Madras rice shoots at 45 dap

\begin{tabular}{|c|c|c|c|c|c|c|c|}
\hline $\begin{array}{l}\text { Concentration of 'Unitas } \\
\text { Super' LOF }\left(\mathrm{ml} \mathrm{L}^{-1}\right)\end{array}$ & Total N & Total P & Ash & Kalium & Calsium & Organic C & $\mathrm{C} / \mathrm{N}$ \\
\hline & & 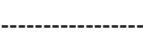 & ------- & ----(\%)---. & ------------. & ------------- & \\
\hline 0 & 2.92 & 1.14 & 23.62 & 2.92 & 0.37 & 33.41 & 11.48 \\
\hline 50 & 2.52 & 1.15 & 20.86 & 3.00 & 0.37 & 32.80 & 14.17 \\
\hline 100 & 2.64 & 1.29 & 21.31 & 2.81 & 0.36 & 32.28 & 12.78 \\
\hline Mean & 2.70 & 1.20 & 21.90 & 2.91 & 0.37 & 32.80 & 12.80 \\
\hline CV LOF (\%) & 7.91 & 15.49 & 13.37 & 7.70 & 12.00 & 7.82 & 10.65 \\
\hline cv. Cisokan* & $1.91-2.10$ & $0.35-0.48$ & 14.70 & 1.22 & 0.32 & 49.59 & 23.61 \\
\hline cv. Pandan Wangi** & $1.68-2.35$ & $0.36-0.42$ & 14.93 & $1.27-1.50$ & $0.29-0.32$ & 48.23 & 20.52 \\
\hline LSD 5\% & 5.87 & & & & & & \\
\hline
\end{tabular}

Source: *) (Jamilah, Fadhila, \& Mulyani, 2017a); **) (Jamilah \& Helmawati, 2015); (Jamilah et al., 2016).

plants were shorter. The forage weight $(\mathrm{FW})$ was increasing with increasing LOF concentration, although statistically non-significant. The highest forage weight, trimmed at 45 days after planting, reached $5.79 \mathrm{t} \mathrm{ha}^{-1}$, which was observed in the treatment of $100 \mathrm{ml} \mathrm{L}^{-1}$ LOF (Figure 1). Forage from rice plants pruned at 45 days after planting would be eaten up by cattle without leftovers. This shows that the forage contains low fiber so that it is easily digested by the cow's stomach. The quality of the forage of Black Madras purple rice is much higher than that of green leaved rice (Table 2). The average nitrogen content of $2.70 \%$ is related to crude protein content (ranging from $2.70 \mathrm{x}$ $6.25=16,87 \%)$. This is higher than the crude protein content of Kumpai grass (Sari, Ali, Sandi,

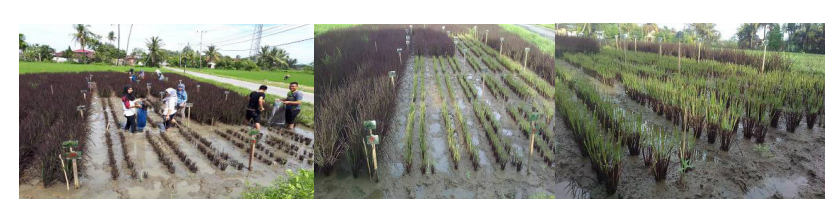

Figure 1. Pruning in Black Madras rice at 45 dap and recovery of vegetative parts 2 weeks after pruning

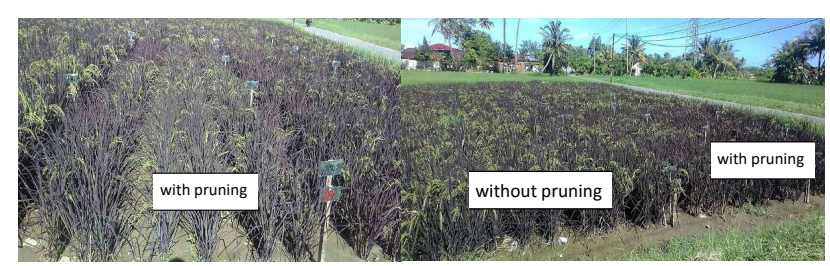

Figure 2. Black Madras rice plants which were pruned and not pruned at $75 \%$ flowering phase
\& Yolanda, 2015) which is only $7.99 \%$ and the crude protein content of grass growing under oil palm plants ranging from 8-10.5\% (Daru, Yuianti, $\&$ Widodo, 2013). Meanwhile, the crude protein content of Calopogonium mucunoides ranges from 2-4\% (Prawiradiputra, Sutedi, Sajimin, \& Fanindi, 2012), and of green leaved rice is $8-14 \%$ (Jamilah, Juniarti, \& Srimulyani, 2016).

Harvesting forage at 45 days after planting will reduce the weight of rice straw at rice harvesting. Based on the data, the pruned plants would loose straw by about $34 \%$, because some of the straw material had been harvested before 45 days after planting. This result has also been reported by (Jamilah \& Helmawati, 2015); (Jamilah et al., 2016); (Jamilah, 2017).

The specialty of the rice plant is that the number of tillers and harvest age were not affected by pruning carried out in 45 days after planting. Plants that were pruned and those that were not pruned can be physiologically matured simultaneously (Figure 2). This can be a promotion that is useful for farmers to be able to cut their forages, without reducing the number of productive tillers and slowing down the harvesting of grain products. In Figure 2, it can be seen that plants that were pruned and not pruned were flowering simultaneously. However, the plants that were not pruned produced flowers 
Table 3. Effects of pruning and concentration of 'Unitas Super' LOF on the yield components of Black Madras rice

\begin{tabular}{|c|c|c|c|c|c|c|}
\hline $\begin{array}{c}\text { Concentration of 'Unitas Super' } \\
\text { LOF }\left(\mathrm{ml} \mathrm{L}^{-1}\right)\end{array}$ & $\begin{array}{l}\text { Panicle } \\
\text { length }\end{array}$ & $\begin{array}{c}\text { Number of grain } \\
\text { per panicle }\end{array}$ & $\begin{array}{l}\text { Weight of } \\
1000 \text { seeds }\end{array}$ & $\begin{array}{l}\text { Empty } \\
\text { grain }\end{array}$ & $\begin{array}{l}\text { Weight of grain } \\
\text { per hectare }\end{array}$ & $\begin{array}{l}\text { Harvest } \\
\text { Index }\end{array}$ \\
\hline & $(\mathrm{cm})$ & Bulir & (g) & $(\%)$ & $\mathrm{Mg}$ & \\
\hline \multicolumn{7}{|l|}{ without pruning } \\
\hline 0 & 28.33 & 164.17 & 23.80 & 29.77 & 3.60 & 0.55 \\
\hline 50 & 28.83 & 184.83 & 24.20 & 30.27 & 4.04 & 0.59 \\
\hline 100 & 28.17 & 165.17 & 24.97 & 35.37 & 3.83 & 0.57 \\
\hline Mean & $28.44 \mathrm{a}$ & $171.39 a$ & $24.32 \mathrm{a}$ & $31.80 \mathrm{a}$ & $3.82 \mathrm{a}$ & $0.57 \mathrm{a}$ \\
\hline \multicolumn{7}{|l|}{ with pruning } \\
\hline 0 & 25.17 & 138.83 & 23.27 & 31.97 & 3.72 & 0.66 \\
\hline 50 & 26.33 & 128.50 & 23.20 & 34.43 & 3.48 & 0.71 \\
\hline 100 & 26.17 & 147.00 & 22.47 & 38.30 & 3.61 & 0.64 \\
\hline Mean & $26.17 \mathrm{~b}$ & $147.00 \mathrm{a}$ & $22.47 \mathrm{~b}$ & $38.30 \mathrm{a}$ & $3.61 \mathrm{a}$ & $0.64 a$ \\
\hline CV pruning (\%) & 4.59 & 11.64 & 2.38 & 27.02 & 6.59 & 8.76 \\
\hline CV LOF (\%) & 4.61 & 17.10 & 3.79 & 9.87 & 17.98 & 6.75 \\
\hline LSD 5\% & 2.53 & & 1.14 & & & \\
\hline
\end{tabular}

Means followed by the same lower case letters in the same column are not significantly different according to LSD at $5 \%$.

more evenly. After flowering, pruning is indistin- from LOF to plants that can be directly absorbed by guishable through the appearance of the plant. plants and function for metabolism. The function

The effect of 'Unitas Super' LOF concentration on the content of N, P, K, Ca and ash was not statistically significant presented in Table 2 . In general, the total N-level of forage in Black Madras rice plants was higher than in green leaved rice plants (cv. Cioskan and cv. Pandan Wangi). Even the crude protein content found in Black Madras increased by $20 \%$ compared to green leaved rice, such as cv. Cisokan (Jamilah et al., 2017b; Almuhaimin, 2017) and Pandan Wangi (Hendra, 2016; Rocki, 2016; Joni, 2017). of the element $\mathrm{P}$ (phosphorus) in plants is involved in energy transfer because it is a component of ATP and ADP, phospholipids, nucleic acids and several coenzymes (Mengel, Kirkby, Kosegarten, \& Appel, 2001). Adequacy of $P$ elements in rice plants will help increase soil metabolism activities such as assimilation $\mathrm{C}$ and $\mathrm{N}$ and increase grain production.

The treatment of pruning and concentration of 'Unitas Super' LOF on the generative parts of Black Madras rice plants significantly decreased panicle length and weight of 1000 seeds, but did

The content of total $\mathrm{N}$, ash, calcium and organic $\mathrm{C}$ was higher in plants treated with $0 \mathrm{ml} \mathrm{L}^{-1}$ LOF and there was a tendency to decrease if the LOF concentration was increased to $100 \mathrm{ml} \mathrm{L}^{-1}$. However, the potassium content and $\mathrm{C} / \mathrm{N}$ ratio were higher in plants given $50 \mathrm{ml} \mathrm{L}^{-1} \mathrm{LOF}$ while the phosphorus content increased when higher LOF concentration was given. The role of LOF in increasing the phosphorus content of forage crops is due to a significant contribution of phosphate not affect the amount of grain per panicle and grain weight per hectare as presented in Table 3 and Figure 3. Crops pruned will lose a lot of assimilation through leaves transported from the field. Most of the stored assimilates in the leaves will be lost. Besides, the remaining assimilates on the part of the plant that is not pruned will produce new leaf to replace the part of the leaves lost due to pruning. This mechanism results in a large amount of energy lost. However, there was a uniqueness of 


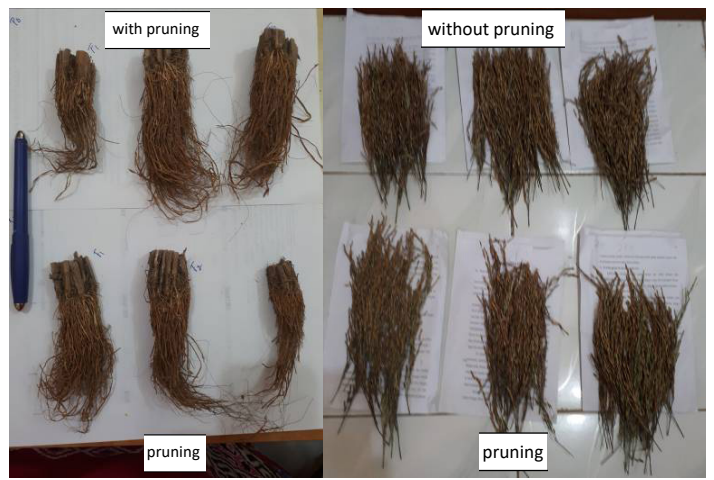

Figure 3. Rooting and rice panicles with and without pruning, from left to right $F 1, F 2$, and F3, respectively

rice plants which due to pruning had lost a lot of energy, but were still able to produce grain weight that was not significantly different compared to plants that were not pruned.

Due to the great loss of plant metabolic products, the pruned plants reduced the length of panicles and the size of rice grains. The panicle length of pruned rice plants was $26.17 \mathrm{~cm}$, while the panicle length of rice plants which were not pruned was $28.44 \mathrm{~cm}$. Similarly for the weight of 1000 seeds, the pruned rice plants only reached $22.47 \mathrm{~g}$, while those that were not pruned could reach $24.32 \mathrm{~g}$. However, the effect of pruning did not significantly reduce rice grain yield per plot or per hectare. The appearance of rice rooting and grain is shown in Figure 3.

Pruning did not produce significantly different root and grain performance compared to nonpruned rice plants. According to the images, the effects of 'Unitas Super' LOF can be clearly seen. The rooting system and grains of rice plants which were not pruned but given $50 \mathrm{ml} \mathrm{L}^{-1}$ of 'Unitas Super' LOF resulted in greater performance compared to other rooting systems or grains of plants given other concentrations of LOF. Conversely, in pruned rice plants, the application of $0 \mathrm{ml} \mathrm{L}^{-1}$ LOF resulted in better root and grain performance compared to other POC concentrations.

\section{CONCLUSION}

Pruning reduced the weight of 1000 seeds and panicle length, but did not reduce the yield of harvested dry grain and harvest index of Black Madras purple rice. The provision of 'Unitas Super' Liquid Organic Fertilizer did not significantly increase the growth and yield of Black Madras rice. The highest dry grain yield was $4.04 \mathrm{t} \mathrm{ha}^{-1}$ observed in plants which were not pruned and treated with $50 \mathrm{ml} \mathrm{L}^{-1}$ 'Unitas Super' LOF.

\section{ACKNOWLEDGEMENT}

Great gratitude is conveyed to the Chairperson of the Tamansiswa University Institute for Research and Community Service (LPPM) who helped with some of this research funding. The authors would also like to thank Dahlia as a laboratory assistant, the students who have helped a lot in the field experiment, and the research team, who worked well until the completion of this study.

\section{REFERENCES}

Almuhaimin Oka Putra. (2017). Efek pemangkasan dan beberapa jenis pupuk organik cair terhadap pertumbuhan salibu tanaman padi varietas Cisokan. Skripsi Fak. Pertanian Unitas, Padang, 44 hal.

Antoni. (2017). pengaruh berbagai jenis pupuk organik cair terhadap pertumbuhan dan hasil padi Pandan Wangi ratoon. Skripsi S1 Program Studi Agroteknologi, Universitas Tamansiswa Padang.

BPS.( 2016). Produksi Padi Menurut Provinsi (ton), 1993-2015. https://www.bps.go.id/ dynamictable/2015/09/09/865/ produksi-padi-menurut-provinsi-ton-1993-2015.html

Daru, T. P., Yuianti, A., \& Widodo, E. (2013). Sebagai Pakan Sapi Potong Di Kabupaten Kutai Kartanegara. Pastura, 3(2), 94-98. Jamilah. (2017). Pengaruh Pupuk Organik Cair Asal C.odorata Terhadap Serapan Hara Kalium Dan Hasil Padi Ladang. Jurnal Bibiet, 1(1), 17-26.

Jamilah, Fadhila, R., \& Mulyani, S. (2017a). Farm Analysis Of Rice Crop Trimmed Periodically. In International Conference on Social, Humanities and Government Science (ICSHGS) 2017 (pp. 202-211). Palembang: Universitas Tamansiswa Palembang. Jamilah, Fadhila, R., \& Mulyani, S. (2017b). Farm analysis of rice crop trimmed periodically in the tropical wet. In International Conerence on Social, Humanities and Government Science (Vol. 1, p. 631). https://doi.org/10.1016/S0969-4765(04)00066-9 
Jamilah, \& Helmawati. (2015). Kajian Analisis Usaha Tani Integrasi Padi Sawah dan Pakan Ternak Ruminansia Menunjang Kedaulatan Pangan dan Daging Dalam Menghadapi Masyarakat Ekonomi Asean 2015. In Seminar Nasional Kesiapan Indonesia dalam Menghadapi Pasar Bebas Asean Melalui Penguatan Implementasi Corporate Governance yang Sehat (Vol. 3, pp. 254-266). Padang: Perpustakaan Nasional RI.

Jamilah, Juniarti, \& Srimulyani. (2016). Potensi tanaman padi yang dipupuk dengan kompos C hromolaena odorata; penghasil gabah dan sumber hijauan pakan ternak penunjang ketahanan pangan. In PROS SEM NAS MASY BIODIV INDON (Vol. 2 , pp. 27-31). Masyarakat Biodiversitas Indonesia. https://doi. org/10.13057/psnmbi/m020105
Mengel, K., Kirkby, E. a., Kosegarten, H., \& Appel, T. (2001). Principles of Plant Nutrition (Vol. 5th). https://doi.org/10.1007/978-94010-1009-2

Prawiradiputra, B. R., Sutedi, E., Sajimin, \& Fanindi, A. (2012). Hijauan pakan ternak untuk lahan sub-optimal. Jakarta: Badan Penelitian Dan Pengembangan Pertanian Kementerian Pertanian. Retrieved from Badan Penelitian Dan Pengembangan Pertanian Kementerian Pertanian

Sari, M. L., Ali, A. I. M., Sandi, S., \& Yolanda, A. (2015). Kualitas Serat Kasar , Lemak Kasar , dan BETN terhadap Lama Penyimpanan Wafer Rumput Kumpai Minyak dengan Perekat Karaginan. Pertanian Sriwijaya, 4(2), 35-40. 